\title{
Implementasi Protokol Kesehatan CHSE dalam Meningkatkan Kepercayaan Tamu di Hotel
}

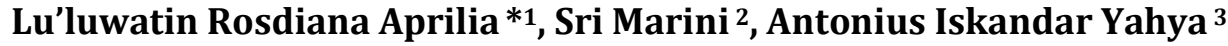 \\ Akademi Pariwisata NHI Bandung \\ Email: lulu@akparnhi.ac.id
}

\begin{abstract}
Abstrak
Dampak covid-19 telah memberikan perhatian lebih kepada sektor pariwisata. Tingkat ancaman dan resiko dari pandemi Covid-19 secara signifikan mengurangi niat wisatawan untuk menginap di hotel CHSE merupakan kebijakan yang diterapkan oleh pemerintah khususnya oleh Kemenparekraf RI dalam mencegah meluasnya pandemic Covid-19 di Indonesia. CHSE mengusung bersih, sehat, aman dan lingkungan yang ramah. Tren tamu saat ini adalah memilih tempat yang bersih dan aman dari covid-19. Tujuan penelitian ini adalah untuk mengetahui implementasi protokol Kesehatan CHSE di hotel, untuk mengetahui tingkat kepercayaan tamu untuk menginap dan mengetahui factor-faktor yang mempengaruhi implementasi CHSE. Metode penelitian menggunakan pendekatan kualitatif. Informan dalam Penelitian ini adalah 3 General Manager dari Hotel yang dipilih, 15 tamu dari masing- masing Hotel serta studi dokumentasi. Teknik analisis data yang digunakan adalah analisis data kualitatif yang dilakukan secara interaktif melalui proses data reduction, data display, dan verification. Hasil penelitian menunjukkan bahwa implementasi protocol kesehatan CHSE sudah cukup berhasil dalam meningkatkan kepercayaan tamu untuk menginap. Tamu memiliki kepercayaan dengan adanya sertifikat CHSE yang dipajang di hotel dan media promosi lainnya menjadi satu jaminan penularan covid-19 dapat dieliminir. Faktor internal seperti dukungan sarana dan prasarana Kesehatan dan faktor eksternal yaitu adanya kerjasama dan koordinasi antar pihak terkait, kebijakan publik dan kesadaran pelanggan sangat mempengaruhi implementasi protocol Kesehatan CHSE.
\end{abstract}

Keywords: Protokol Kesehatan; CHSE; Kepercayaan Tamu; Covid-19

\begin{abstract}
The impact of COVID-19 has given more attention to the tourism sector. The level of threat and risk from the Covid-19 pandemic has significantly reduced the intention of tourists to stay at hotels. CHSE is a policy implemented by the government, especially by the Indonesian Ministry of Tourism and Creative Economy in preventing the spread of the Covid-19 pandemic in Indonesia. CHSE promotes a clean, healthy, safe and friendly environment. The current guest trend is to choose a place that is clean and safe from COVID-19. The purpose of this study was to determine the implementation of the CHSE Health protocol in hotels, to determine the level of trust of guests to stay and to determine the factors that influence the implementation of CHSE. The research method uses a qualitative approach. The informants in this study were 3 General Managers of the selected hotels, 15 guests from each hotel and the study of documentation. The data analysis technique used is qualitative data analysis which is carried out interactively through the process of data reduction, data display, and verification. The results showed that the implementation of the CHSE health protocol was quite successful in increasing guest confidence to stay. Guests have confidence that the CHSE certificate displayed at the hotel and other promotional media is a guarantee that the transmission of covid-19 can be eliminated. Internal factors such as the support of Health facilities and infrastructure and external factors, namely the cooperation and coordination between related parties, public policies and customer awareness greatly affect the implementation of the CHSE Health protocol.
\end{abstract}

Keywords: Protokol Kesehatan; CHSE; Kepercayaan Tamu; Covid-19

* Corresponding author

Received: September 02, 2021; Revised: November 11, 2021; Accepted; November 18, 2021 


\section{A. PENDAHULUAN}

Pandemi telah menghadapkan industri perhotelan dengan tantangan yang belum pernah terjadi sebelumnya. Strategi untuk meratakan kurva COVID-19 seperti penguncian komunitas, jarak sosial, perintah tinggal di rumah, pembatasan perjalanan dan mobilitas telah mengakibatkan penutupan sementara banyak bisnis perhotelan dan secara signifikan menurunkan permintaan untuk bisnis yang diizinkan untuk terus beroperasi (Bartik, Bertrand, Cullen, Glaeser, Luca \& Stanton, 2020). Pembatasan yang ditempatkan pada perjalanan dan perintah tinggal di rumah yang dikeluarkan oleh pihak berwenang menyebabkan penurunan tajam dalam hunian dan pendapatan hotel, khususnya hotel-hotel di sekitar daerah Cikole-Lembang, padahal setiap pekan dan musim selalu penuh dan banyak dikunjungi oleh wisatawan atau tamu yang menginap. Sebagian besar pelanggan (lebih dari 50\%) tidak bersedia melakukan perjalanan ke suatu tujuan dan menginap di hotel dalam waktu dekat. Hanya sekitar sepertiga yang bersedia melakukan perjalanan ke suatu tempat dan menginap di hotel dan sekitar seperempat dari pelanggan yang sudah makan di restoran dan dalam beberapa bulan setelah adanya New Normal Era (Gursoy, D., Chi, C. G., \& Chi, O. H., 2020). Hal ini menandakan kepercayaan tamu untuk berkunjung menjadi berkurang.

Banyaknya hotel ditutup dalam masa lockdown yang diberlakukan pemerintah selama pandemi COVID-19 menjadi tantangan bagaimana mengomunikasikan penangangan virus corona untuk memotivasi para tamu untuk berkunjung (Barreto, Loureiro, Braun, Sthapit, Zenker, 2021). Strategi promosi bukan hanya sekedar solusi dalam meningkatkan rasa percaya tamu untuk menginap di hotel, salah satu cara adalah dengan adanya protocol Kesehatan yang diterapkan di Hotel. Strategi hotel hijau/sehat untuk pemulihan pariwisata setelah gelombang pertama COVID19 di China ditujukan untuk mendukung pemulihan pariwisata berkelanjutan yang berfokus pada lingkungan fisik yang hijau/sehat setelah krisis kesehatan juga dapat diterapkan di negara dan wilayah lain yang mengalami situasi yang sama (Gangwei Cai, Lei Xu, Weijun Gao, 2020).

Strategi ini sama dengan CHSE di Indonesia yang mengusung bersih, sehat, aman dan lingkungan yang ramah. Tren tamu saat ini adalah memilih tempat yang bersih dan aman dari covid-19, ini baru bisa terwujud jika tenaga kerjanya juga memahami dan menerapkan prinsip CHSE (Cleanliness, Healthy, Safety, dan Environment) dalam kehidupan sehari-hari dan dalam tugasnya (Prakoso, F A, 2020). Sesuai dengan Panduan CHSE (Kemenparekraf, 2020) bahwa kriteria dalam penerapan protokol Kesehatan CHSE. Kriteria tersebut menjadi patokan dalam implementasi prokes CHSE. Adanya program pemerintah yang diadaptasi oleh pengelola hotel dipercaya akan meningkatkan kepercayaan tamu terhadap hotel. Kepercayaan tamu hotel dapat diperoleh melalui pemenuhan kebutuhan tamu terhadap pelayanan prima yang bersih, sehat, aman dan ramah lingkungan melalui CHSE, dengan demikian kegiatan sektor perhotelan dapat kembali berjalan dengan baik (Fair, D.D, 2020). Ketika diterapkan dengan tepat dan disiplin, CHSE ini diharapkan akan meningkatkan kepercayaan tamu untuk menginap di Hotel.

Berdasarkan fenomena tersebut, peneliti merasa perlu diadakan penelitian mengenai hal-hal yang mewujudkan adanya kondisi yang meningkatkan kepercayaan tamu untuk menginap di hotel melalui adanya implementasi protokol kesehatan CHSE.

\section{B. METODE PENELITIAN}

Pendekatan penulisan yang digunakan oleh peneliti adalah dengan menggunakan pendekatan kualitatif. Dalam menggunakan pendekatan kualitatif ini peneliti akan memahami dengan seksama serta menggambarkan tentang fenomena sosial dan peristiwa yang terjadi dengan cara melakukan 
wawancara, pengamatan dan melakukan pemeriksaan terhadap dokumen yang ada, dalam hal ini berkaitan dengan pelaksanaan implementasi protokol Kesehatan CHSE.

Menurut Lofland (dalam Moleong, 2006) sumber data utama dalam penelitian kualitatif ialah kata-kata, dan tindakan, selebihnya adalah data tambahan seperti dokumen dan lain-lain. Yang dimaksud kata-kata dan tindakan disini yaitu kata-kata dan tindakan orang yang diamati atau diwawancarai merupakan sumber data utama (primer). Sedangkan sumber data lainnya bisa berupa sumber tertulis (sekunder), dan dokumentasi seperti foto.

Berbagai sumber tersebut yakni data primer adalah key informan yang berasal dari Internal dan eksternal Hotel, Data observasi. Kemudian, Sumber data sekunder yang berasal dari dokumendokumen yang berkaitan dengan permasalahan yang diteliti. Dalam penelitian ini, dokumen yang digunakan antara lain : Room Count Sheet, Keputusan Menteri Kesehatan Republik Indonesia Nomor "HK.01.07/MENKES/382/2020", SOP Penerapan Protokol Kesehatan Hotel, Panduan Protokol Kesehatan CHSE dari Kemenparekraf, dan Dokumen lain yang dirasa perlu.

Teknik pengumpulan data dalam penelitian kualitatif adalah teknik pengumpulan data utama yaitu observasi participant, wawancara mendalam, studi dokumentasi, dan gabungan atau trianggulasi (Sugiyono, 2008). Teknik analisis data menggunakan metode analisis kualitatif yang merupakan kajian menggunakan data-data teks, persepsi, dan bahan-bahan tertulis lain untuk mengetahui hal-hal yang tidak terukur dengan pasti (intangible). Analisis data secara kualitatif bersifat hasil temuan secara mendalam melalui pendekatan bukan angka atau nonstatistik (Istijanto, 2008). Jadi penelitian kualitatif tidak memiliki rumus atau aturan absolut untuk mengolah dan menganalisis data.

\section{HASIL DAN ANALISIS}

\section{Gambaran Umum Hotel di Masa Pandemi Covid-19}

Gambaran kondisi hotel di masa pandemi covid-19 pada awal tahun 2020, occupancy stabil tapi keadaan berubah setelah adanya virus covid-19. Terjadi penurunan occopancy pada bulan April dan Mei karena mengikuti kebijakan pemerintah. Awal Juni mulai ada peningkatan kunjungan seiring dengan pelonggaran PPKM. Kemudian, adanya issue dampak dari pandemi menjadikan operasional sempat dihentikan oleh manajemen. Pada bulan April dan Mei mengikuti kebijakan pemerintah. Awal Juni atau sekitar Juli mulai ada peningkatan kunjungan seiring dengan Masa Adaptasi Kebiasaan Baru (AKB). Hal tersebut dibuktikan dengan adanya perubahan drastis yang tertuang dalam data tingkat huni kamar dari ketiga hotel yang diteliti. Kondisi di awal pandemi berubah secara drastis, namun pada saat memasuki era AKB, keadaan kembali pulih walaupun tidak sestabil seperti di awal sebelum pandemi.

Kondisi hotel yang seperti ini menjadi pemandangan biasa, namun pemerintah harus memiliki cara agar bisa kembali pulih dan naik kembali. Menyikapi kondisi tersebut, pengelola hotel telah melakukan upaya terobosan dalam rangka memelihara dan meningkatkan kepercayaan tamu untuk menginap di hotel dengan memberlakukan dan menerapkan protokol kesehatan CHSE. Implementasi prokes CHSE ini didasarkan pada Keputusan Menteri Kesehatan Nomor HK.01.07/Menkes/382/2020. Selain itu, ada juga Keputusan Menteri Kesehatan Nomor HK.01.07/Menkes/382/2020. Pada Kepmen tersebut dapat dilihat bahwa pengelola hotel berhak meberlakukan protokol kesehatan CHSE dan bahkan menjadi suatu kewajiban.

\section{Implementasi Protokol Kesehatan CHSE di Hotel}

Implementasi protokol Kesehatan CHSE bila dikaitkan dengan teori implementasi berdasarkan unsur adanya target. Implementasi merupakan sebuah tindakan yang dilakukan baik 
secara individu maupun kelompok dengan maksud untuk mencapai tujuan yang telah dirumuskan. Individu ataupun kelompok bisa dikatakan suatu organisasi (Wijaya, R \& Supardo, S, 2006; Grindle, 1980 dalam Pasolong H, 2007). Atas dasar tersebut, bahwa setiap organisasi merupakan unsur yang sangat penting dalam masyarakat modern baik di sektor publik (negara) maupun di sektor swasta. Dalam masyarakat modern seperti Indonesia masa kini dikenal berbagai macam organisasi seperti rumah sakit, sekolah, universitas, yayasan, badan usaha milik negara dan kantor-kantor pemerintah. Dalam administrasi negara, organisasi merupakan unsur yang utama karena menyangkut kerjasama antara orang-orang yang terlibat dalam kegiatan-kegiatan yang saling berhubungan untuk mencapai tujuan-tujuan publik seperti pembangunan dan pelayanan masyarakat. Temuan penelitian terkait implementasi CHSE ini dilihat berdasarkan kriteria yang ada dalam pedoman CHSE, yang dapat dilihat pada tabel berikut ini:

Tabel 2. Hasil Observasi Implementasi Aspek Cleanlines dalam Protokol Kesehatan CHSE di Hotel

\begin{tabular}{|c|c|c|c|}
\hline Aspek CHSE & Sindang Reret Hotel & $\begin{array}{c}\text { Terminal Wisata } \\
\text { Grafika }\end{array}$ & Puteri Gunung Hotel \\
\hline Cleanliness & $\begin{array}{l}\text { Dengan adanya SOP } \\
\text { implementasi unsur } \\
\text { Clean dalam penerapan } \\
\text { protocol kesehatan } \\
\text { CHSE. Unsur kebersihan } \\
\text { telah sesuai dengan } \\
\text { indikator Clean dalam } \\
\text { CHSE sehingga baik } \\
\text { pengunjung maupun } \\
\text { karyawan terjamin dari } \\
\text { segi kebersihan dengan } \\
\text { fasilitas yang disediakan } \\
\text { hotel. }\end{array}$ & $\begin{array}{l}\text { Adanya SOP implementasi } \\
\text { unsur Clean dalam } \\
\text { penerapan protocol } \\
\text { kesehatan CHSE. Unsur } \\
\text { kebersihan telah sesuai } \\
\text { dengan indikator Clean } \\
\text { dalam CHSE sehingga baik } \\
\text { pengunjung maupun } \\
\text { karyawan terjamin dari } \\
\text { segi kebersihan dengan } \\
\text { fasilitas yang disediakan } \\
\text { hotel. }\end{array}$ & $\begin{array}{lr}\begin{array}{l}\text { Adanya } \\
\text { pelaksanaan }\end{array} & \text { SOP } \\
\text { Clean } & \text { dalam } \\
\text { penerapan } & \text { protocol } \\
\text { kesehatan } & \text { CHSE. } \\
\text { Unsur kebersihan } \\
\text { telah sesuai dengan } \\
\text { indikator Clean dalam } \\
\text { CHSE sehingga baik } \\
\text { pengunjung maupun } \\
\text { karyawan terjamin } \\
\begin{array}{l}\text { dari segi kebersihan } \\
\text { dengan fasilitas yang } \\
\text { disediakan hotel. }\end{array}\end{array}$ \\
\hline Healthy & $\begin{array}{l}\text { Pengunjung wajib } \\
\text { memakai masker di } \\
\text { lokasi. Demikian juga } \\
\text { dengan karyawan } \\
\text { menggunakan masker } \\
\text { dan face shield dan } \\
\text { sarung tangan. } \\
\text { Ketersediaan APD pada } \\
\text { saat diperlukan juga } \\
\text { belum memenuhi unsur } \\
\text { healthy dalam protokol } \\
\text { kesehatan CHSE. }\end{array}$ & $\begin{array}{l}\text { Penerapan unsur healthy } \\
\text { dalam protokol kesehatan } \\
\text { CHSE secara umum telah } \\
\text { diterapkan dengan baik. } \\
\text { Terutama hotel ini } \\
\text { memiliki Kerjasama yang } \\
\text { baik dengan puskesmas } \\
\text { terdekat bahkan ada } \\
\text { ruangan khusus yang } \\
\text { digunakan } \\
\text { puskesmas CIkole untuk }\end{array}$ & $\begin{array}{lr}\text { Penerapan } & \text { unsur } \\
\text { healthy dalam } \\
\text { protokol kesehatan } \\
\text { CHSE di Puteri Gunung } \\
\text { secara umum telah } \\
\text { diterapkan dengan } \\
\text { baik. }\end{array}$ \\
\hline Safety & $\begin{array}{l}\text { Belum terdapat SOP bagi } \\
\text { penyelamatan diri dari } \\
\text { bencana. Untuk unsur } \\
\text { Safety hal tersebut } \\
\text { sangat penting. } \\
\text { Demikian juga dengan } \\
\text { peringatan berupa sign } \\
\text { untuk memastikan alat- } \\
\text { alat elektronik dalam } \\
\text { kondisi mati bagi }\end{array}$ & $\begin{array}{l}\text { Belum terdapat SOP bagi } \\
\text { penyelamatan diri dari } \\
\text { bencana. Demikian juga } \\
\text { dengan peringatan } \\
\text { berupa sign untuk } \\
\text { memastikan alat-alat } \\
\text { elektronik dalam kondisi } \\
\text { mati bagi karyawan dan } \\
\text { mekanisme komunikasi } \\
\text { penanganan kondisi }\end{array}$ & $\begin{array}{lr}\text { Belum terdapat } & \text { SOP } \\
\text { bagi penyelamatan diri } & \text { bencana. } \\
\text { dari } & \text { bencan } \\
\text { Demikian juga dengan } & \text { peringatan berupa } \\
\text { sign } & \text { untuk } \\
\text { memastikan alat-alat } & \text { elektronik dalam } \\
\text { kondisi mati } & \text { bagi } \\
\text { karyawan } & \text { dan }\end{array}$ \\
\hline
\end{tabular}

4 | Jurnal Kepariwisataan: Destinasi, Hospitalitas dan Perjalanan, Volume 5 Nomor 2, 2021: 1-7 


\begin{tabular}{|c|c|c|c|}
\hline Aspek CHSE & Sindang Reret Hotel & $\begin{array}{c}\text { Terminal Wisata } \\
\text { Grafika }\end{array}$ & Puteri Gunung Hotel \\
\hline & $\begin{array}{lr}\text { karyawan } & \text { dan } \\
\text { mekanisme komunikasi } \\
\text { penanganan kondisi } \\
\text { darurat belum tersedia. } \\
\text { Hal tersebut perlu } \\
\text { penekanan karena } \\
\text { menyangkut keamanan } \\
\text { baik pekerja maupun } \\
\text { tamu hotel dan resort. }\end{array}$ & $\begin{array}{l}\text { darurat belum tersedia. } \\
\text { Hal tersebut perlu } \\
\text { penekanan karena } \\
\text { menyangkut keamanan } \\
\text { baik pekerja maupun } \\
\text { tamu hotel dan resort }\end{array}$ & $\begin{array}{l}\text { mekanisme } \\
\text { komunikasi } \\
\text { penanganan } \\
\text { darurat } \\
\text { tersedia. }\end{array}$ \\
\hline $\begin{array}{l}\text { Environ- } \\
\text { mental }\end{array}$ & 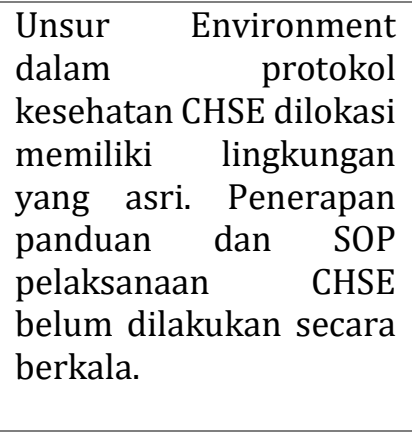 & $\begin{array}{l}\text { Penerapan unsur } \\
\text { Environment dalam } \\
\text { protokol kesehatan CHSE } \\
\text { dilokasi memiliki } \\
\text { lingkungan yang asri. } \\
\text { Pemantauan dan evaluasi } \\
\text { penerapan panduan dan } \\
\text { SOP pelaksanaan CHSE } \\
\text { telah dilakukan secara } \\
\text { berkala }\end{array}$ & $\begin{array}{lr}\text { Penerapan } & \text { unsur } \\
\text { Environment dalam } & \text { protokol kesehatan } \\
\text { CHSE rilokasi } \\
\text { memiliki lingkungan } \\
\text { yang asri. Penerapan } \\
\text { panduan dan SOP } \\
\text { pelaksanaan CHSE } \\
\text { telah dilakukan secara } \\
\text { berkala. }\end{array}$ \\
\hline
\end{tabular}

Sumber: Hasil Olahan penulis, 2021

Berdasarkan tabel 2, dapat dilihat implementasi CHSE di setiap aspek diterapakan dengan baik, namun ada beberapa kriteria yang belum dilaksanakan secara konsisten terkhusus yang berkaitan dengan SOP.

Maka bila dikaitkan antara hasil temuan dengan teori yang ada, pelaksanaan implementasi protocol Kesehatan CHSE dapat dikatakan sudah cukup berhasil, namun belum maksimal karena masih ditemukan adanya ketidak konsistenan pelaksanaan SOP serta masih adanya ketakutan dari masyarakat untuk keluar rumah dan menginap di hotel, padahal telah dipromosikan dan dibranding bahwa dengan adanya protokol Kesehatan ini akan menjamin keselamatan, kemanan, Kesehatan dan lingkungan dari tamu hotel. Seperti yang dapat dilihat pada gambar berikut:
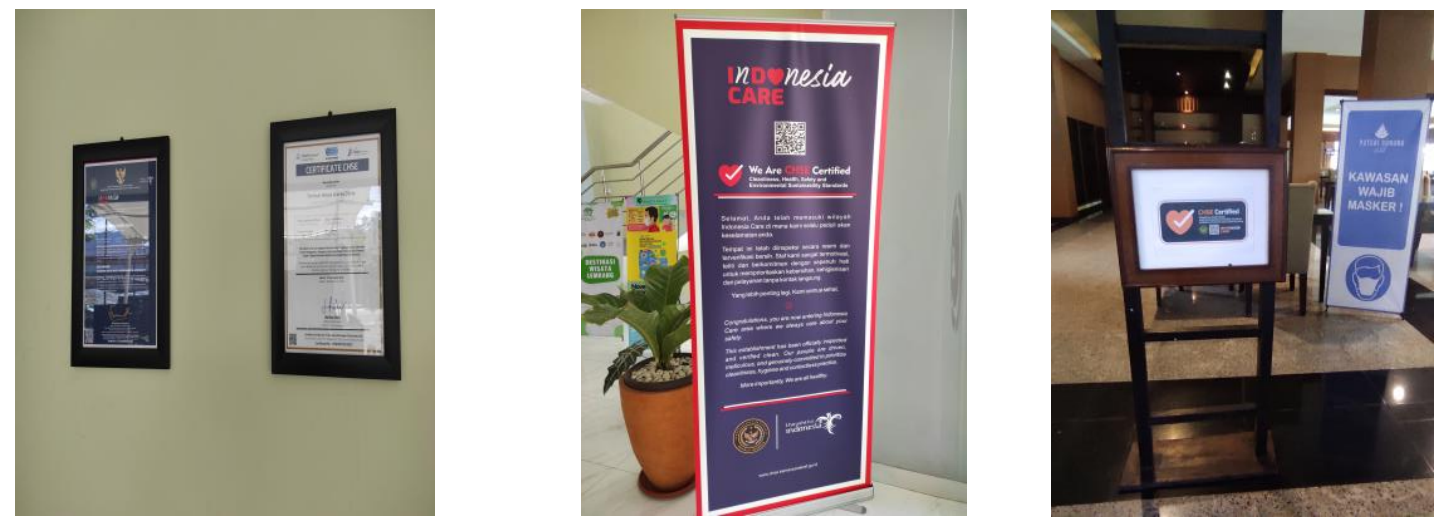

Gambar 1 Bukti Branding dan Promosi Terkait Sertifikat CHSE

Sumber: Pribadi, 2021 


\section{Kondisi Tingkat Kepercayaan Tamu untuk Menginap di Hotel di Masa Pandemi Covid-19}

Total tingkat brand reliability responden terhadap hotel di masa pandemi covid-19 secara keseluruhan meningkat dan percaya menginap di hotel melalui ada nya CHSE dikarenakan hotel menginformasikan sertifikat CHSE dan banner telah tersertifikasi CHSE sehingga tamu memiliki kepercayaan lebih terhadap hotel.

Total tingkat brand intention responden terhadap hotel di masa pandemi covid-19 secara keseluruhan dalam kategori cukup dengan skor rata-rata 77,33\%. Kekahwatiran tamu menginap dapat dieliminir dengan adanya kepercayaan tamu akan sertifikasi dan implementasi CHSE oleh hotel. Apabila dikaitkan dengan hasil temuan tingkat kepercayaan tamu untuk menginap di hotel sudah cukup meningkat dengan diberlakukannya protocol Kesehatan CHSE hal ini sesuai dengan tujuan utama dari adanya CHSE dalam pemulihan pariwisata setelah adanya pandemic covid-19.

\section{Faktor-faktor yang mempengaruhi Implementasi Protokol Kesehatan CHSE}

Faktor internal yang mempengaruhi implementasi protokol kesehatan CHSE adalah adanya dukungan sarana dan prasarana protokol kesehatan untuk menerapkan CHSE.

Sedangkan faktor eksternal yang mempengaruhi implementasi protokol kesehatan CHSE yaitu adanya kerjasama dan koordinasi antar pihak terkait, kebijakan publik dan kesadaran pelanggan atau tamu. Kebijakan yang dikeluarkan oleh pemerintah juga menjadi faktor yang juga mempengaruhi implementasi protokol CHSE di hotel, karena hal ini berkaitan dengan mobilisasi tamu yang akan dating dan menginap di hotel. Percuma prokes CHSE-nya dibuat bagus dan sesuai standar namun apabila masih ada kebijakan seperti PSBB dan PPKM, hal ini akan membatasi tamu khususnya yang berasal dari luar Bandung Raya, apalagi sekarang ada kebijakan ganjil genap bagi kendaraan berplat luar Bandung (selain plat D). tentu hal ini akan membuat masyarakat yang menjadi calon tamu menjadi malas untuk dating ke Lembang, sekalipun untuk meeting dan kepentingan bisnis. Kesadaran pelanggan juga menjadi salah satu pengaruh terimplementasinya prokes CHSE di hotel ini, karena apabila tidak ada kesadaran dari para pelanggannya untuk berkunjung dan apalagi sampai menginap ke hotel maka akan percuma walaupun hotel tersebut sudah tersertifikasi CHSE.

\section{SIMPULAN}

Berdasarkan hasil analisis terhadap temuan penelitian dapat disimpulkan Implementasi protocol kesehatan CHSE sudah cukup berhasil. Hal ini dibuktikan dari hasil penelitian yang menggambarkan bahwa implementasi protocol Kesehatan CHSE ini sudah mampu meningkatkan kepercayaan tamu untuk menginap di hotel yang digambarkan melalui peningkatan tingkat occupancy.

Kondisi Tingkat kepercayaan tamu untuk menginap sudah cukup meningkat dengan diberlakukannya protocol Kesehatan CHSE di hotel hal ini dibuktikan dari hasil penelitian yang menggambarkan bahwa sebagian besar percaya dengan adanya sertifikat CHSE yang dipajang di hotel dan media promosi lainnya menjadi satu jaminan penularan Covid-19 dapat dieliminir.

Faktor-faktor yang mempengaruhi implementasi protokol kesehatan CHSE dibedakan menjadi dua faktor yaitu Faktor internal dan eksternal. Faktor internal yang meliputi dukungan sarana dan prasarana implementasi CHSE. Sedangkan faktor eksternal, meliputi kerjasama dan koordinasi antar pihak terkait, kebijakan publik dan kesadaran pelanggan.

Rekomendasi untuk mewujudkan protokol kesehatan CHSE yang lebih meningkatkan kepercayaan tamu untuk menginap, maka perlu dilakukan beberapa upaya. Perlu dilaksanakan promosi dan branding mengenai CHSE agar informasi tersampikan secara komprehensif dan ketakutan masyarakat

6 | Jurnal Kepariwisataan: Destinasi, Hospitalitas dan Perjalanan, Volume 5 Nomor 2, 2021: 1-7 
berkurang. Selain itu perlunya meningkatkan koordinasi dan kerjasama antar pihak yang berkaitan langsung dengan implementasi CHSE.

\section{UCAPAN TERIMA KASIH}

Penelitian ini didanai dan bersumber dari (DIPA) Dirjen Dikti, Kemendikbudristek Tahun Anggaran 2021, Nomor SP DIPA-023.17.1.690439/2021 revisi ke-04 tanggal 4 Juni 2021. Kami mengucapkan terima kasih kepada segenap pihak, khususnya pengelola hotel dan tamu Sindang Reret Cikole, Terminal Wisata Grafika Cikole dan Puteri Gunung Hotel yang menjadi narasumber yang telah memberikan segalanya, baik secara langsung ataupun tidak langsung. Ucapan yang sama kepada reviewer atas komentarnya yang sangat menyempurnakan naskah ini. Semoga Pandemi covid-19 segera berakhir dan kepariwisataan Indonesia segera pulih.

\section{DAFTAR REFERENSI}

Bartik, A. W., Bertrand, M., Cullen, Z. B., Glaeser, E. L., Luca, M., \& Stanton, C. T. (2020). How are small businesses adjusting to COVID-19? Early evidence from a survey (No. w26989). National Bureau of Economic Research

Devy Dwi Fajri. (2020). Pelatihan Penerapan Protokol Kesehatan Karyawan Hotel di Masa Tatanan Normal Baru, Jurnal Abdimas Pariwisata Vol. 1 No. 2 Tahun 2020; hal 60-65

Fajar Adi Prakoso. (2020). Dampak Coronavirus Disease (Covid-19) Terhadap Industri Food \& Beverages: Jurnal Manajemen Bisnis (JMB). 2020; 33 (1), 1-6

Gangwei Cai, Lei Xu, Weijun Gao. (2021). The green B\&B promotion strategies for tourist loyalty: surveying the restart of Chinese national holiday travel after COVID-19, International Journal of Hospitality Management, Volume 94, 2021, https://doi.org/10.1016/j.ijhm.2020.102704.

Gursoy, D., Chi, C. G., \& Chi, O. H. (2020). COVID-19 Study 2 Report: Restaurant and Hotel Industry: Restaurant and hotel customers' sentiment analysis. Would they come back? If they would, WHEN? (Report No. 2), Carson College of Business, Washington State University.

Istijanto. (2008). Riset Sumber Daya Manusia. Gramedia: Jakarta

Jano Jiménez-Barreto, Sandra Loureiro, Erik Braun, Erose Sthapit, Sebastian Zenker. (2021). Use numbers not words! Communicating hotels' cleaning programs for COVID-19 from the brand perspective, International Journal of Hospitality Management, Volume 94, 2021, https://doi.org/10.1016/j.ijhm.2021.102872.

Kemenparekraf. Protokol Kesehatan CHSE. (2020) https://pedulicovid19.kemenparekraf.go.id/siaranpers- tingkatkan-kepercayaan- wisatawan-kemenparekraf-sosialisasi-protokol-kesehatan/

Maleong, L. (2006). Metode Penelitian Kualitatif. Remaja Rosdakarya: Bandung

Pasolong, Harbani. (2007). Teori Administrasi Publik. Alfabeta: Bandung

Sugiyono. (2016). Metode Penelitian Pendidikan (Pendekatan Kuantitatif, Kualitatif dan R\&D). Alfabeta: Bandung 